\title{
HISTORIA SAGRADA Y LOA SACRAMENTAL EN CALDERÓN*
}

\author{
VANESSA FORTUÑO GÓMEZ \\ Universitat de Barcelona
}

\section{Tiempo E Historia en las LoAs SACRAMENTAleS}

Estudiar el uso de la historia sagrada en las loas sacramentales de Calderón implica plantearse el problema del tiempo en todas las piezas sacramentales, ya que, la ausencia de tiempo en la obra dramática, y por tanto de cronología, impediría hablar de Historia, pues no es propiamente histórico aquello que se halla sub specie aeternitatis. Como mucho, se podría hacer referencia a personajes que el espectador sabe históricos o a parcelas temporales que se han convertido en simultáneas y han

\footnotetext{
${ }^{*}$ Recibido: 11-03-2009 Aceptado: 12-05-2009
} 
perdido su sentido histórico. Y así sería, en efecto, de continuar vigentes las teorías que, durante décadas, habían considerado atemporal el auto sacramental1; ninguna voz se alzaba en contra de esa definición, que había pasado ya a las historias del teatro español². Sin embargo, Arellano ha esclarecido la cuestión:

Calderón no anula el tiempo y espacio en sus alegorías, ni prescinde de ellos; prescinde de ciertas constricciones de su manipulación. La libertad omnímoda que le conceden las doctrinas poéticas de la época y sobre todo el peculiar mecanismo alegórico, le permiten, por el contrario, una potenciación compleja de estos aspectos, una presencia no nula, sino más bien proteica, en la que los tiempos y los espacios dramáticos se multiplican en facetas extraordinarias, se transmutan, se funden o interrelacionan en todas las maneras posibles $[\ldots] .^{3}$

El plano historial del auto no pierde nunca la temporalidad. Es sólo en el plano alegórico donde el dramaturgo se permite dar un nuevo sentido a ese tiempo, o, incluso, ofrecer un atisbo de eternidad:

Espacio y tiempo se transmutan, alcanzan otras dimensiones espirituales, pasan al plano del significado alegórico, pero no anulan su significado historial. Los personajes de diferentes épocas y mundos se reúnen en la proyección alegórica, o prefiguran otros posteriores, componentes todos de un proceso diseñado por Dios, en quien todo es presente. ${ }^{4}$

Estas reflexiones son en cierto modo válidas para las loas sacramentales; y, de hecho, Arellano incluye entre sus ejemplos la Loa en metáfora de la piadosa Hermandad del Refugio. En concreto, en las loas sacramentales de Calderón, el plano historial se sitúa en una fecha determinada, justamente el día en que tiene lugar la representación. Para empezar, en casi todas las piezas los propios personajes anuncian que es el día de Corpus Christi:

\footnotetext{
${ }^{1}$ Acerca de esta tradición crítica, vid. I. Arellano y J. E. Duarte, El auto sacramental, Madrid, Laberinto, 2003, p. 48.

2 Por ejemplo, Ruiz Ramón resume así las ideas en curso: “[...] la transposición alegórica del mundo sacramental conlleva, como reflejo obligado, la atemporalización propia del auto sacramental, cuya «historia» dramática transcurre fuera de todo tiempo histórico", / (F. Ruiz Ramón, Historia del teatro español (Desde sus orígenes hasta 1900), Madrid, Cátedra, 1996 (9a ed.), p. 273).

${ }^{3}$ I. Arellano, Estructuras dramáticas y alegóricas en los autos de Calderón, Pamplona / Kassel, Universidad de Navarra / Reichenberger, 2001, p. 118.

${ }^{4}$ Ibid., pp. 121-122.
} 


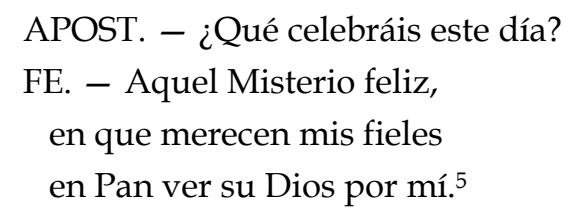

Además, se añade, por lo general, información suficiente para ubicar la acción no sólo en un día de Corpus indeterminado, sino del mismo año del siglo XVII que están viviendo los espectadores. El texto de la loa de El Año Santo de Roma llega incluso a encerrar en él la fecha de su representación:

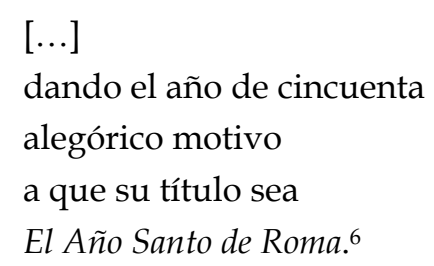

En ocasiones, la condición de "drama contemporáneo" se sugiere en la loa sacramental a partir de las alusiones históricas y geográficas. En la loa de Llamados y escogidos, al igual que en la Europa del siglo XVII, la Apostasía reina en las provincias del Norte 7 . Por otro lado, es harto evidente que el argumento de la loa de La vacante general se desarrolla en 1648, año del restablecimiento de las representaciones ${ }^{8}$ :

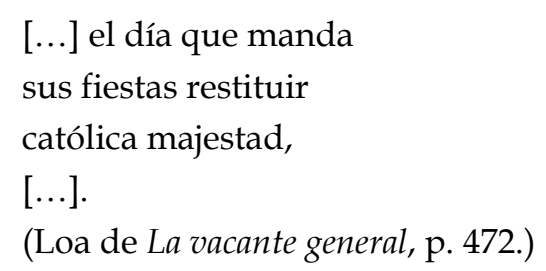

También la acción de la loa de La Hermandad del Refugio sucede en el Madrid del siglo XVII. Y en las loas de El viático cordero y El verdadero Dios Pan, la mención,

\footnotetext{
${ }^{5}$ P. Calderón de la Barca, "Loa para el auto sacramental intitulado La vacante general", en Obras completas. Tomo III: Autos sacramentales, ed. Á. Valbuena Prat, Madrid, Aguilar, 1952, p. 470. Todas las citas de la loa se tomarán de esta edición, así como las de las loas de Llamados y escogidos, El divino Orfeo, El viático cordero, El verdadero Dios Pan y El indulto general.

${ }^{6}$ A partir de aquí, el texto de la loa de El Año Santo de Roma se citará siempre por la edición de I. Arellano, "Para el repertorio de loas sacramentales calderonianas. Un autógrafo inédito de Calderón: la loa auténtica de El Año Santo de Roma", Criticón, 62 (1994), pp. 7-32. Este primer fragmento se halla en la p. 22.

7 Vid. Loa de Llamados y escogidos, p. 454.

8 Vid. E. Cotarelo y Mori, Ensayo sobre la vida y obras de D. Pedro Calderón de la Barca, Madrid / Frankfurt am Main, Iberoamericana / Vervuert, 2001, p. 267.
} 
respectivamente, de Felipe IV y de Carlos II no deja lugar a dudas. Sólo una de las ocho loas analizadas aquí 9 , en concreto la de El indulto general, no es contemporánea en el plano historial, sino que, atravesando ya el umbral alegórico, sitúa el argumento en el período histórico de la Ley Natural y aplaza hasta el auto la instauración de la Ley de Gracia:

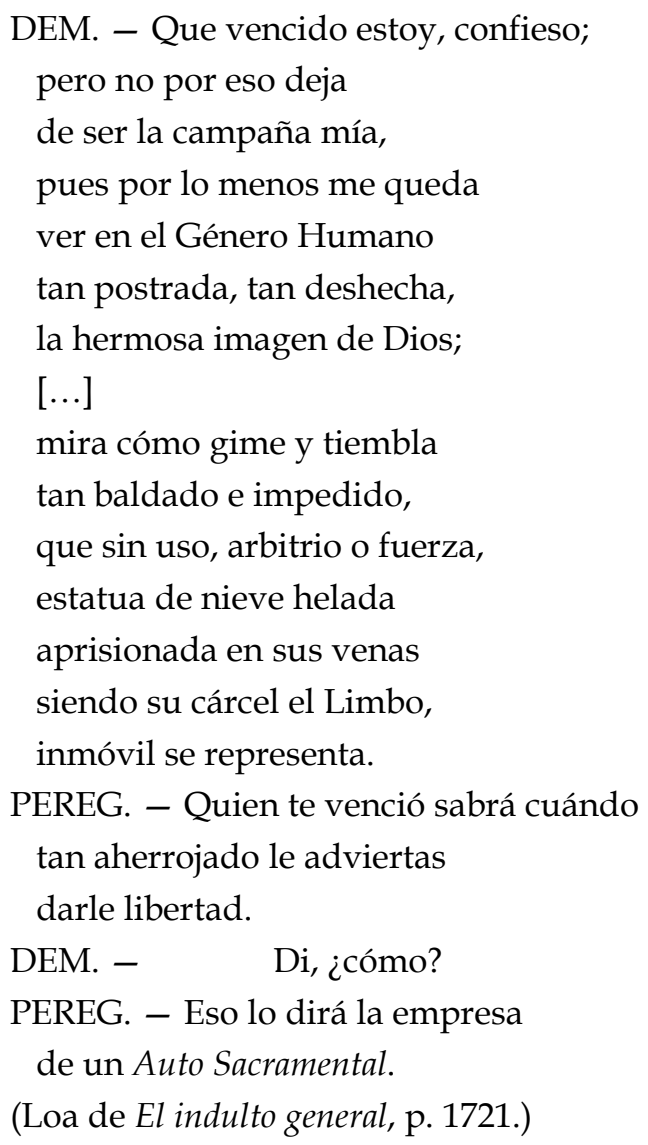

En efecto, el plano alegórico de las loas sacramentales de Calderón no sólo no es tampoco atemporal sino que tiene la virtud de condensar - de forma más o menos cronológica - la historia teológica de la Humanidad, es decir, la historia de la Redención, que culmina con la Ley de Gracia que instituye Jesucristo a través de la Eucaristía, tras las dos edades anteriores en las que reinan respectivamente la Ley Natural y la Ley Escrita ${ }^{10}$. En la loa de La vacante general, por ejemplo, el Santísimo

\footnotetext{
${ }^{9}$ Se trata de las loas de Llamados y escogidos, La vacante general, El Año Santo de Roma, La Hermandad del Refugio, El divino Orfeo (segunda versión), El viático cordero, El verdadero Dios Pan y El indulto general.

10 Este alcance alegórico del argumento es asimismo el más frecuente en el auto sacramental calderoniano y, por tanto, los estudios de Rull al respecto son también de todo punto necesarios para
} 
recorre durante la fiesta del Corpus las calles de Madrid, cuya topografía mística similar a la que encontraremos en La Hermandad del Refugio - permite alegorizar la Redención:

\author{
FE. $[\ldots]$ \\ Ese embozado galán \\ del cristalino viril, \\ sale de Santa María, \\ [...]. \\ A la calle nueva llega \\ y nueva para salir \\ a la gran Plaza del Mundo, \\ en cuyo sitio advertir \\ debes, que su principal \\ fábrica, heroica y gentil, \\ la Casa es del Pan, en cuyos \\ umbrales contribuir \\ verás sus frutas al año; \\ no es ocasión de inferir \\ que el agrio de la manzana \\ se quita con Pan; $[\ldots]$. \\ Aquí a su piadoso oído \\ llegó el clamar y el gemir \\ de los presos de la cárcel, \\ [...]; y él \\ compadecido de oír \\ sus lamentos, prometió \\ sus prisiones redimir. \\ Con que pasó a Santa Cruz \\ con deseo de cumplir \\ su Palabra; [...]. \\ En todo el orbe se oyó, \\ desde el cénit al nadir \\ su triunfo: El Correo Mayor \\ lo diga, pues a esparcir
}

la comprensión de las loas. Vid. E. Rull, “El auto sacramental de Calderón como género. Un ejemplo: Psiquis y Cupido", en A. Egido (ed.), Lecciones calderonianas, Zaragoza, Ibercaja, 2001, p. 138; E. Rull, "Hacia la delimitación de una teoría político-teológica en el teatro de Calderón", en L. García Lorenzo (ed.), Calderón. Actas del «Congreso Internacional sobre Calderón y el Teatro Español del Siglo de Oro». (Madrid, 8-13 de junio de 1981), Madrid, C.S.I.C., 1983, t. II, pp. 759-767; y E. Rull, “Apuntes para un estudio sobre la función teológico-política de la «loa» en el Siglo de Oro", en I. Arellano et alii (eds.), Apuntes sobre la loa sacramental y cortesana. Loas completas de Bances Candamo. Estudios y ediciones críticas, Kassel, Reichenberger, 1994, pp. 25-35. 
las nuevas envió inferiores

ministros, a cuyo fin

les dió sus postas el tiempo

y la fama su clarín.

(Loa de La vacante general, pp. 471-472.)

En alguna de las loas no se resume la historia de la Salvación, pero se constata de igual modo la actualidad de la Ley de Gracia; por lo que también se presupone la existencia de un tiempo anterior a ésta y, en consecuencia, la realidad del tiempo como estado opuesto a la eternidad. Es el caso de la loa de Llamados y escogidos, en la que San Pablo advierte a Asia ${ }^{11}$ que "no ha de haber otra venida" (p. 454), o el de la loa de El viático cordero, donde se verifica que "a un sacrificio / Dios de oblación incruenta / todo lo ceremoniado / de la anciana ley abrevia" (p. 1155). En esta última pieza, por otro lado, las Horas, es decir, los husos horarios, se convierten en personajes, y un reloj forma parte de la escenografía, de modo que al tiempo histórico se añade un tiempo artificial, desmenuzado, que preocupaba especialmente al hombre barroco.

En realidad, siendo cierto todo lo dicho hasta aquí, esto es, que, en el plano historial, las loas sacramentales suelen tener lugar en un día de Corpus del siglo XVII y, en el alegórico, resumir la historia de la Redención, no dejarían de hallarse incongruencias si se analizaran las piezas perdiendo de vista su carácter sacramental. Como era presumible, son numerosos los anacronismos - así, la presencia de San Pablo como personaje de la loa de Llamados y escogidos - y otras licencias como, por ejemplo, el desorden cronológico que se observará en la historia sagrada alegorizada en La Hermandad del Refugio. Lo que nos interesaba aquí era únicamente comprobar la temporalidad de las loas sacramentales de Calderón y así se ha hecho. Sólo en unos versos, pertenecientes a la loa de El Año Santo de Roma, el Día Primero de la Creación le recuerda a la Naturaleza la inexistencia del tiempo hasta ese momento:

\footnotetext{
${ }^{11}$ En esta loa, Asia representa el Judaísmo, Europa el Cristianismo, África el Ateísmo y América la Idolatría; de manera que "se centra en Europa el mensaje de la Tercera Edad teológica" (E. Rull, "Apuntes para un estudio sobre la función teológico-política...", p. 34). En esta elección ve Rull motivos políticos.
} 


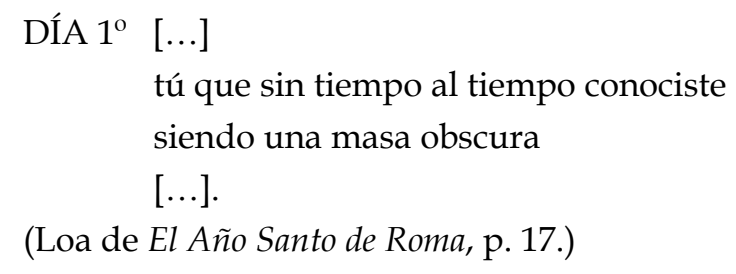

Además de autorizar el estudio de la historia sagrada, el breve examen del tiempo en las loas sacramentales ha servido para acercarnos a la idea que Calderón tiene de la Historia desde el punto de vista filosófico. Sin duda, es una concepción teológica y lineal, pues la Providencia ha trazado un designio de progreso. El devenir de la historia humana, aparentemente arbitrario en otros géneros dramáticos, adquiere con el uso de la alegoría un sentido cristiano, y, aunque Dios sí exista fuera del tiempo, el hombre ha recorrido varios períodos históricos antes de ser redimido. Se trata de la concepción de la Historia que nació con San Agustín ${ }^{12}$, en la que tanto la oposición entre tiempo y eternidad como el concepto de Gracia son fundamentales.

\section{LA HISTORIA SAGRADA}

La historia sagrada es la materia histórica propia de los géneros sacramentales. Por historia sagrada entendemos las narraciones históricas contenidas en la Biblia, pero en estas piezas - frente a lo que pueda ocurrir, por ejemplo, en los dramas - los santos reciben un trato muy similar, por lo que su examen será conjunto. Cabe advertir, por otro lado, que no es éste el lugar para señalar las fuentes bíblicas o patrísticas de los versos de los autos y loas sacramentales de Calderón, excepto en algún caso particular. Esa labor, además de haber sido realizada con gran acierto por algunos editores de los textos (en especial en la edición del GRISO de la Universidad de Navarra), superaría con creces el espacio de este trabajo, sin llegar a aportar información apreciable para sus conclusiones, porque se trata de fuentes muchas veces apenas modificadas - precisamente por la necesidad de mantener la doctrina

\footnotetext{
12 También Rull opina que la teoría calderoniana de las Tres Edades del Mundo "parece inspirada en San Agustín” (E. Rull, “Hacia la delimitación de una teoría político-teológica...”, p. 760).
} 
de la Iglesia - y de las que nos interesa la función que puedan cumplir dentro de la obra de Calderón, pero no el origen exacto ${ }^{13}$.

La preeminencia de la historia sagrada en las loas sacramentales se ratifica en el hecho de que el único personaje histórico dramatizado en las piezas inspeccionadas pertenezca justamente a esa categoría. Se trata de San Pablo, protagonista de la loa de Llamados y escogidos ${ }^{14}$, quien, en el plano historial, es el maestro de armas en un torneo de esgrima entre las cuatro partes del mundo ${ }^{15}$. El combate alegórico atañe a la Eucaristía, pues, siendo llamadas al Banquete, las partes del mundo -incluso Europa - dudan y se enzarzan en una discusión. Gracias a Pablo, que pone orden en el enfrentamiento deportivo y dialéctico, Europa vuelve a creer, vence en el torneo, ocupa el mejor asiento en el convite, al que acude el resto de personajes excepto la Apostasía, y ofrece un auto a la Sabiduría. En realidad, ni el desarrollo de la loa ni su feliz desenlace serían posibles sin el continuo recuerdo de la Palabra de Dios por parte del apóstol, que incluso recurre a sus propios escritos:

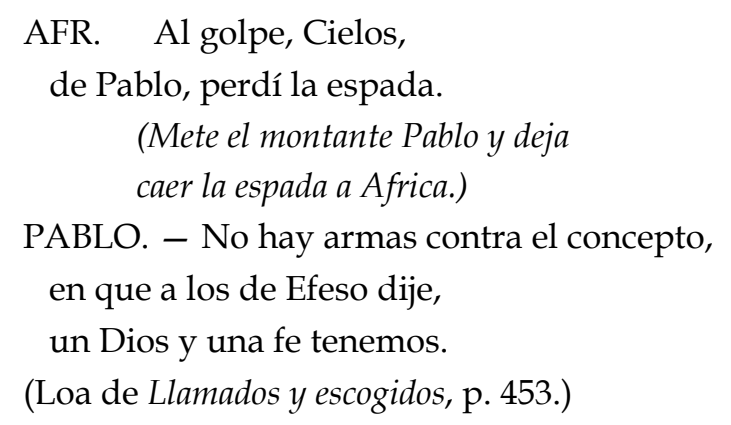

Es más, sin el personaje de Pablo, ni siquiera existiría la propia loa, nacida como ofrenda suya a la Sabiduría:

\footnotetext{
13 "La presencia de la Biblia en los autos sacramentales calderonianos es vastísima, y exigiría un libro entero muy documentado y detallado, en el que un estudioso igualmente versado en la Biblia y en la obra calderoniana examinara los distintos modos de uso, adaptaciones y funcionalidades dramáticas y doctrinales de los intertextos bíblicos, etc." (I. Arellano, Estructuras dramáticas y alegóricas..., p. 59). 14 "Llama la atención la frecuencia con la que se suele citar a San Pablo en este tipo de loas" (K. Spang, "Aproximación a la loa sacramental y palaciega: notas estructurales", en Apuntes sobre la loa sacramental y cortesana..., p. 17).

15 Esta loa se ajusta, así, al paradigma compositivo de los juegos de destreza. Vid. I. Arellano, Estructuras dramáticas y alegóricas..., pp. 31-32.
} 


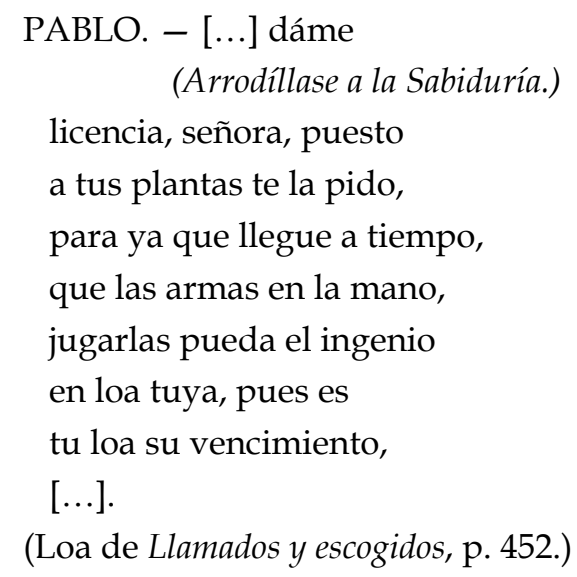

Evidentemente, el mismo papel de defensor de la Sabiduría mediante argumentos extraídos de la Biblia y de obras teológicas lo realizan personajes no históricos en otras loas. Sin embargo, es significativa la elección de San Pablo por la autoridad que ha de tener su testimonio ante los espectadores ${ }^{16}$. Es el mismo crédito que se le atribuye cuando, en aras de explicar el sacramento de la Eucaristía, se le cita en las loas de El divino Orfeo (p. 1836) y de El verdadero Dios Pan (p. 1237). Sólo en la loa de La Hermandad del Refugio será distinta la función que cumpla la mención de San Pablo:

\begin{tabular}{|c|c|}
\hline FEE & $\begin{array}{l}\text { Un bizarro caballero, } \\
\text { precipitado y altivo, } \\
\text { cayó de un caballo y fue } \\
\text { tan grande su precipicio } \\
\text { que quedó ciego. Por él } \\
\text { yo, señora, te suplico. }\end{array}$ \\
\hline CARIDAD & ¿Tú, Fee? \\
\hline FEE & $\begin{array}{l}\text { Sí, porque su vida } \\
\text { me ha de ser de gran servicio. }\end{array}$ \\
\hline CARIDAD & ¿Dónde fue? \\
\hline FEE & $\begin{array}{l}\text { En la Corredera } \\
\text { de San Pablo. }\end{array}$ \\
\hline CARIDAD & $\begin{array}{l}\text { Ya adivino } \\
\text { sus señas: ¿no es en la hebrea } \\
\text { lengua el más docto rabino? }\end{array}$ \\
\hline $\mathrm{EE}$ & Sí es. \\
\hline
\end{tabular}

\footnotetext{
16 Además, nadie podía cumplir mejor el papel de maestro de armas, pues el montante con que separa los combates y corta las disputas es el mismo que le acompaña en la iconografía posterior al Concilio de Trento. Vid. J. Carmona Muela, Iconografía de los santos, Madrid, Istmo, 2003, pp. 351-352.
} 


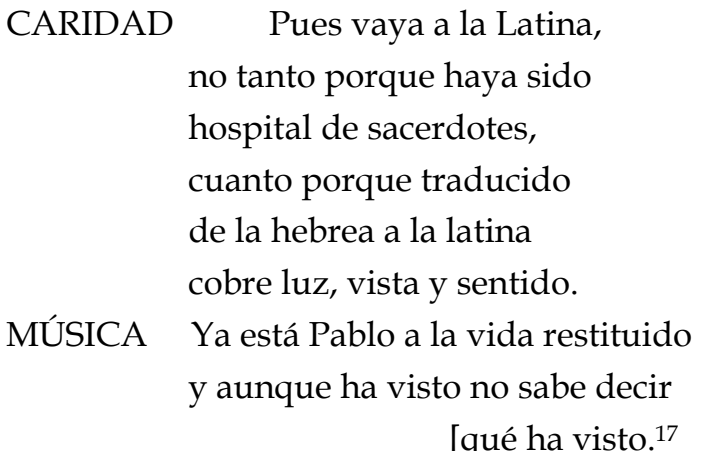

Inscrito en la lectura de los memoriales que los necesitados madrileños han depositado en la Hermandad del Refugio (sobre cuyo sentido alegórico volveremos después)18, este pasaje presenta a un San Pablo legendario - caído del caballo, como marca la tradición - y se centra en el momento de su conversión, para dibujarlo como uno de los innumerables beneficiarios de la historia de la Salvación. En este caso, no interesan sus escritos, sino su vida; pese a que la intención de ilustrar la doctrina cristiana más relacionada con la Eucaristía se repite.

Aparte de San Pablo, que es el único que con toda propiedad se puede clasificar así, sería posible considerar también personaje de historia sagrada con texto al Demonio. Éste, que aparece en la loa de El indulto general, presenta en todo el teatro barroco dos caras simultáneas, la histórica y la alegórica, ya se halle en piezas sacramentales, ya en otros géneros; por ejemplo, como ha estudiado Ingrid Simson, en comedias de temática americana:

“[...] para el público de aquel entonces se distinguió de las personificaciones de nociones puramente abstractas. Aunque Satanás para los espectadores [...] fue en primer lugar una figura histórica, como incorporación del mal a este mundo, también es considerado como personificación alegórica"19.

\footnotetext{
17 P. Calderón de la Barca, Loa en metáfora de la piadosa Hermandad del Refugio, ed. I. Arellano et alii, Pamplona / Kassel, Universidad de Navarra / Reichenberger, 1998, pp. 50-51. Todas las citas de la loa de La Hermandad del Refugio remiten a esta edición.

18 Como ha observado Arellano, gran parte de esta loa responde al paradigma compositivo de la consulta de memoriales; vid. I. Arellano, Estructuras dramáticas y alegóricas..., pp. 53-54.

${ }^{19}$ I. Simson, "La función de la alegoría en las comedias de temática americana en el Siglo de Oro", en C. Strosetzki (ed.), Teatro español del Siglo de Oro. Teoría y práctica, Frankfurt am Main / Madrid, Vervuert / Iberoamericana, 1998, p. 306.
} 
Es mucho más complejo el estatus de personaje histórico de Dios, ya sea dramatizado o mencionado. Dios no es en sí mismo un personaje histórico porque, a diferencia del hombre, no vive en el tiempo, sino en la eternidad. Por tanto, sería un error considerar su mera mención como una alusión histórica. Sin embargo, algunas de sus acciones se producen dentro del tiempo y modifican la Historia; y de ello hay innumerables muestras ya en el Antiguo Testamento. Además, la culminación de la intervención de Dios en la Historia es su propio nacimiento como hombre. La vida de Jesús sí es histórica y, por consiguiente, cualquier dramatización o alusión a ella no debe dejar de estudiarse. Precisamente, no cabe duda de que la Sabiduría en la loa de Llamados y escogidos ${ }^{20}$ y el Peregrino de la loa de El indulto general representan a Jesucristo. Es lógico que sólo la segunda persona de la Santísima Trinidad, Dios y hombre al mismo tiempo, figure como personaje en un tipo de obra dramática que se caracteriza precisamente por articular esas dos naturalezas del mundo, y siempre bajo una máscara que acentúe aún más esa ambigüedad. En resumen, apenas hay dramatización de la historia sagrada en las loas sacramentales de Calderón, ni en las dramatis personae ni en los argumentos, pero, frente a un posible exceso de abstracción, Calderón procura dejar pequeñas pistas de la historicidad de lo alegorizado.

Ciertamente, si se traslada a las loas sacramentales la clasificación de Arellano de los tres usos principales de la Biblia en los autos de Calderón, esto es, "menciones y adaptaciones de microtextos bíblicos", "macrotextos bíblicos parciales" y "macrotextos bíblicos argumentales"21, sólo los dos primeros -mucho más el primero que el segundo- están representados en las loas, mientras que en ningún caso el argumento está tomado de la historia sagrada. A diferencia del auto, la loa no utiliza la Biblia como materia historial, seguramente porque, en muy breve espacio

\footnotetext{
20 "La sabiduría, que según el sentido bíblico es un atributo de Dios, según la simbología sacramental representa la misma divinidad" (E. Rull, "Apuntes para un estudio sobre la función teológicopolítica...", p. 35).

${ }^{21}$ Vid. I. Arellano, Estructuras dramáticas y alegóricas..., pp. 64-95.
} 
de tiempo, tiene que desentrañar el misterio de la Eucaristía ${ }^{22}$, y para ello ha de primar la discusión teológica sobre la acción. Por eso, el esquema de la loa sacramental calderoniana, concretado en diferentes paradigmas compositivos, es la que Rafael Zafra denomina "estructura de cuestión”, es decir, "una escenificación del método escolástico de la quaestio"23; y esa fidelidad a la concepción de las piezas como debates teológicos acaba por convertirlas - como ha visto Zafra - en más sacramentales que los autos: “En la loa se recuerda y exalta una verdad de Fe [...], y se la celebra con un auto cuyo asunto puede no tener más de eucarístico que la adoración final de la Hostia y el Cáliz"24.

Aunque Calderón no incluye "macrotextos bíblicos argumentales" en las ocho loas sacramentales que comentamos, sí recurre en una ocasión al uso de un "macrotexto bíblico parcial"; concretamente, en la loa de El Año Santo de Roma25, donde los propios Días narran la Creación. Dentro de la contienda entre la Gracia y la Naturaleza, que conforma la estructura de la pieza, este fragmento del Génesis poco modificado, por otra parte - sirve como argumento a la Naturaleza para intentar demostrar su mayor excelencia ${ }^{26}$.

Las más numerosas en las loas sacramentales de Calderón son, sin embargo, las "menciones y adaptaciones de microtextos bíblicos". Aunque, como ha quedado dicho, no es posible detenerse en la infinidad de frases extraídas de la Biblia, se debe prestar atención a las menciones precisas de personajes y hechos de historia sagrada $\mathrm{y}$, sobre todo, determinar la intención del dramaturgo al aludirlos. Al igual que el

22 "EUR.- Divina Sabiduría, / [...] / ¿Sepamos, pues, a qué efecto / nos llamas y qué convite / es el que nos has propuesto?" (Loa de Llamados y escogidos, p. 451). "APOST.- ¿Qué celebráis este día?" (Loa de La vacante general, p. 470). "DAM. 1. ${ }^{\mathrm{C}}$ [...] / la Fe Católica, atenta / a la mayor alabanza / del Misterio que celebra, / saber cuál es el mayor / Atributo suyo intenta" (Loa de El divino Orfeo, pp. 1835-1836).

${ }^{23}$ R. Zafra, "La «estructura de cuestión» en las loas sacramentales calderonianas", en I. Arellano y E. Cancelliere (eds.), La dramaturgia de Calderón: técnicas y estructuras (Homenaje a Jesús Sepúlveda), Madrid / Frankfurt am Main, Iberoamericana / Vervuert, 2006, p. 626.

${ }^{24}$ R. Zafra, art. cit., p. 627.

${ }^{25}$ Vid. I. Arellano, Estructuras dramáticas y alegóricas..., pp. 85-86.

${ }^{26} \mathrm{Vid}$. Loa de El Año Santo de Roma, p. 20. 
extenso relato de la Creación en la loa de El Año Santo de Roma y que la presencia del personaje de Pablo en la loa de Llamados y escogidos, la principal función de las citas bíblicas en las loas sacramentales es servir de argumento a los contendientes de las disputas teológicas que se desarrollan en ellas. Por lo general, se procura explicar el sacramento de la Eucaristía; es el caso de la cita de unas palabras proféticas del rey David:

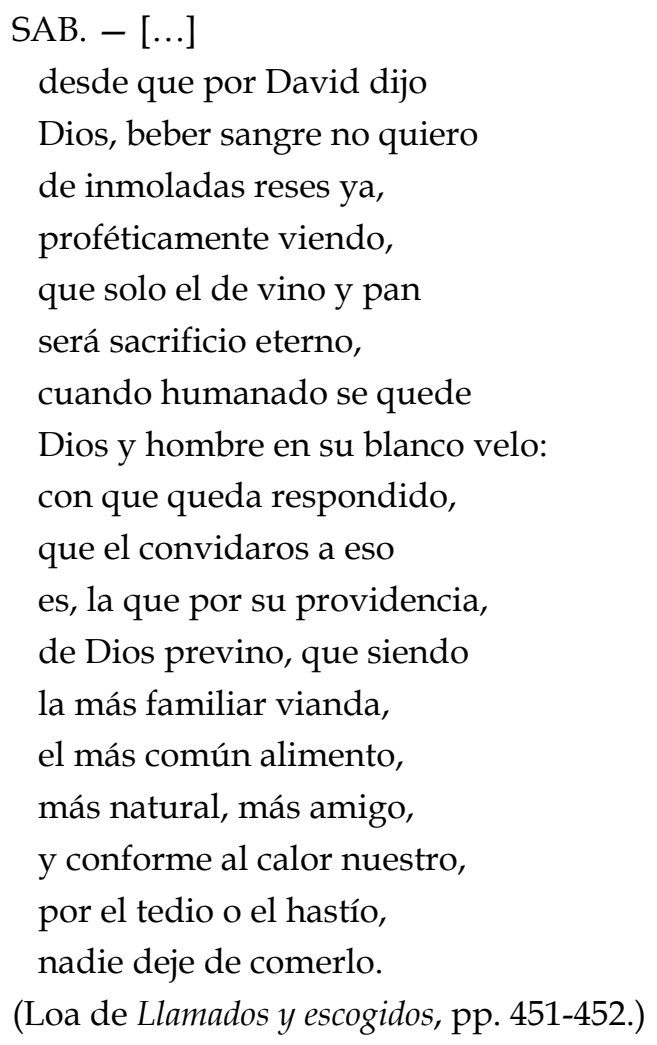

En muchas otras ocasiones se desea justificar la alegría que reina en la celebración del Corpus:

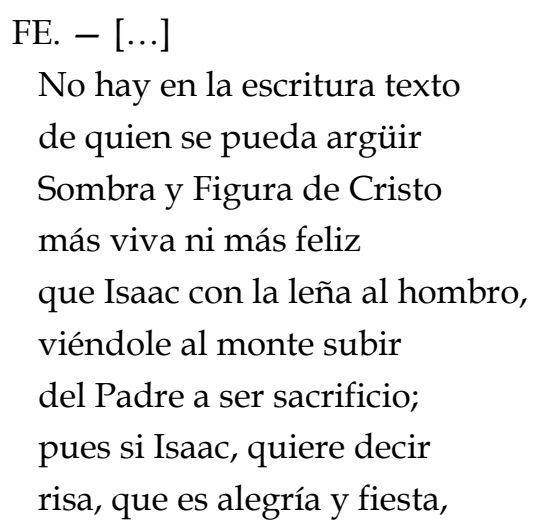




$$
\begin{aligned}
& \text { sobre otros lugares mil } \\
& \text { de cánticos, salmos e himnos } \\
& \text { que persuaden a servir } \\
& \text { a Dios con exaltaciones. } \\
& \text { Bien debemos inferir } \\
& \text { en la luz de aquella sombra, } \\
& \text { que le place ver aquí, } \\
& \text { con devotos regocijos } \\
& \text { sus grandezas aplaudir, } \\
& \text { pues no sin causa previno } \\
& \text { el que hubiese risa allí. } \\
& \text { (Loa de La vacante general, p. 470.) }
\end{aligned}
$$

Este último pasaje demuestra, por otro lado, el uso argumentativo de las contadas prefiguraciones que, en forma de mención, aparecen en las loas sacramentales $^{27}$. Otro ejemplo de ello sería el uso que el Peregrino de la loa de El indulto general hace de Daniel 2, 32-35 en su disputa con el Demonio:

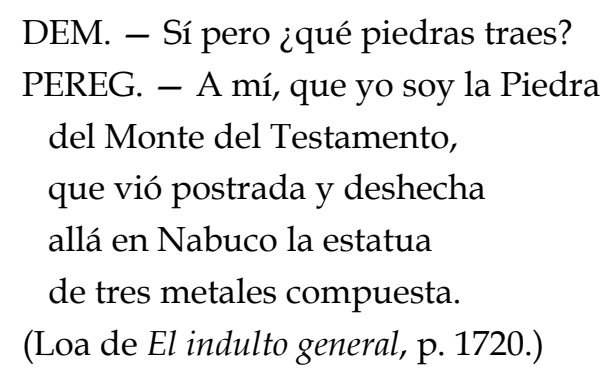

Esta función argumentativa de las intervenciones constituidas por citas bíblicas de distintos tipos es al mismo tiempo - a causa de su cometido persuasivo con respecto a los otros personajes - argumental, pues contribuye a hacer avanzar el texto. En muchos casos, asimismo, son versos que cumplen una tercera función, la alegórica, porque iluminan el plano historial para que veamos el significado alegórico de la circunstancia; por ejemplo, remiten al verdadero sentido del juego de prendas de la loa de El verdadero Dios Pan:

$$
\begin{aligned}
& \text { VERD. - Esperad, que, en el principio, } \\
& \text { la Poesía ha errado. } \\
& \text { POES. } \\
& \text { pues en el principio, dije }
\end{aligned}
$$

\footnotetext{
27 A diferencia de los autos, no hay en estas piezas una alegorización de los hechos del Nuevo Testamento a partir de la teatralización de personajes y sucesos veterotestamentarios.
} 


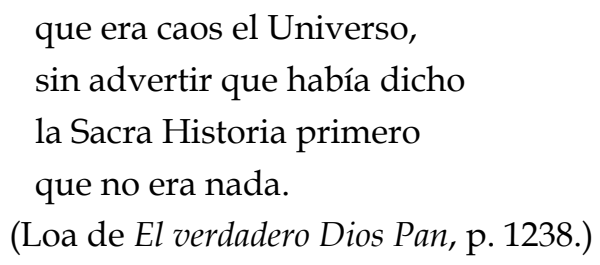

Pero las mismas alusiones, estudiadas desde el punto de vista del espectador, aún cumplen una última función: catequística. Si bien la función didáctica o pedagógica de los autos sacramentales y de la fiesta sacramental en su conjunto ha sido cuestionada en algún estudio ${ }^{28}$, es casi unánime, y suficientemente demostrada, la opinión de que el adoctrinamiento es una de las principales finalidades de este tipo de teatro ${ }^{29}$. El examen por separado de la loa sacramental como género ha llevado a la misma conclusión: "En la finalidad la loa sacramental discrepa de las demás, dado que [...] hallamos una intención didáctica muy precisa y es la de acercar al público el misterio de la Eucaristía"30. Y un detallado estudio de C. Erdocia sobre las loas sacramentales de Calderón ha terminado de fijar la misma finalidad en esas piezas concretas ${ }^{31}$. El análisis de la utilización de la Biblia en estas obras nos proporciona ahora la oportunidad de detectar que es precisamente la mención de elementos de historia sagrada la principal responsable del cumplimiento de la intención catequística de los textos. Algo que, en algún caso como el de la loa de $\mathrm{La}$

\footnotetext{
28 "Al pueblo español no había que instruirle desde el teatro, pues estaba ya suficientemente instruido desde los púlpitos, las misas, las procesiones, las conmemoraciones cíclicas cristianas y los actos más cotidianos de su vida, fuese seglar o eclesiástica" (E. Rull (ed.), Autos sacramentales del Siglo de Oro, Barcelona, Plaza \& Janés, 1986, p. 21).

29 Vid. A. A. Parker, Los autos sacramentales de Calderón de la Barca, Barcelona, Ariel, 1983, p. 53; K. Spang, "El auto sacramental como género literario", en I. Arellano et alii (eds.), Divinas y humanas letras. Doctrina y poesía en los autos sacramentales de Calderón. Actas del Congreso Internacional, Pamplona, Universidad de Navarra, 26 febrero-1 marzo, 1997, Pamplona / Kassel, Universidad de Navarra / Reichenberger, 1997, pp. 504-505; F. B. Pedraza Jiménez, Calderón. Vida y teatro, Madrid, Alianza, 2000, p. 257; E. Rodríguez Cuadros, Calderón, Madrid, Síntesis, 2002, p. 121. Muy ligada a la didáctica, se halla la función litúrgica, la cual, sin embargo, no influye en el texto teatral de forma tan clara, sino que es justamente lo que convierte al auto en algo más que un género dramático; vid.. J. M. Díez Borque, Teoría, forma y función del teatro español de los Siglos de Oro, Palma de Mallorca, José J. de Olañeta, 1996, pp. 136-140.

${ }^{30}$ K. Spang, “Aproximación a la loa...", pp. 17-18.

31 Vid. C. Erdocia Castillejo, Hacia una poética de la representación sacramental del Siglo de Oro español: las loas sacramentales de Calderón de la Barca y la celebración del Corpus Christi, Princeton University, 1997 [tesis doctoral], p. 91.
} 
vacante general, Enrique Rull esbozó hace tiempo, aunque prestando excesiva atención aún al pueblo como receptor del mensaje: “Calderón está explicando, enseñando, adoctrinando, convenciendo al pueblo con argumentos, imágenes, testimonios de todo orden [...]. Lo importante es cómo las imágenes de los propios textos bíblicos acuden a su mente para ilustrar sus propios argumentos" 32 .

El número tan elevado de citas bíblicas con fines catequísticos sólo adquiere sentido si se tiene en cuenta que, según ha demostrado Tietz, el "espectador implícito" de las piezas sacramentales no es el vulgo, sino la elite social y cultural de la Corte $^{33}$. No es que el vulgo no fuese también adoctrinado a través de otros elementos dramáticos e incluso mediante conceptos teológicos ineludibles en la formación de todo católico, pero las múltiples dificultades de cada alusión van dirigidas sólo a una parte del público, o, mejor dicho, a varios de los públicos - salvo el vulgo- que presenciaban los autos durante los días en que éstos eran representados ${ }^{34}$. Con esta excepción, no hay mejor manera de catequizar al espectador de la loa y del auto sacramentales, porque la Historia es ahí un excelente instrumento didáctico a causa de la escasa distancia que hay entre la exposición de la historia sagrada - y más para argumentar verdades de fe- y lo que se conoce como catequesis.

La única función desvinculada de la catequesis que cumplen las "menciones y adaptaciones de microtextos bíblicos" en las loas sacramentales calderonianas es la

\footnotetext{
32 E. Rull, "Instrucción y concelebración populares en el auto sacramental", en J. Álvarez Barrientos y A. Cea Gutiérrez (eds.), Actas de las Jornadas sobre teatro popular en España, Madrid, C.S.I.C., 1987, p. 57. 33 Vid. M. Tietz, "El «espectador implícito» de los autos sacramentales de Pedro Calderón de la Barca", en La dramaturgia de Calderón..., pp. 561-586.

${ }^{34}$ Como expone, entre otros, Díez Borque, si se obvian las modificaciones que pudiese haber de un año a otro, el orden de la representación de los autos en la fiesta del Corpus era el siguiente: el jueves por la tarde se representaban ante los reyes y, a continuación, ante los miembros del Consejo de Estado y del Consejo de Aragón. El viernes por la mañana los distintos públicos estaban formados por el Consejo de la Inquisición, el Consejo de Cruzada y el Consejo de Hacienda. El viernes por la tarde los espectadores eran la Villa de Madrid, el Consejo de Indias y el Consejo de Órdenes. El sábado era el turno, sucesivamente, del presidente del Consejo de Castilla, del pueblo y del Consejo de Italia. Vid. J. M. Díez Borque, Los espectáculos del teatro y de la fiesta en el Siglo de Oro, Madrid, Laberinto, 2002, p. 234.
} 
comparativa, en lo que representa un uso estilístico y, por lo general, caracterizador de personajes. Una muestra de esta lógica preferencia del dramaturgo por los nombres bíblicos a la hora de establecer símiles en el texto de dichas piezas es la siguiente referencia a 1 Samuel 17, 38-39:

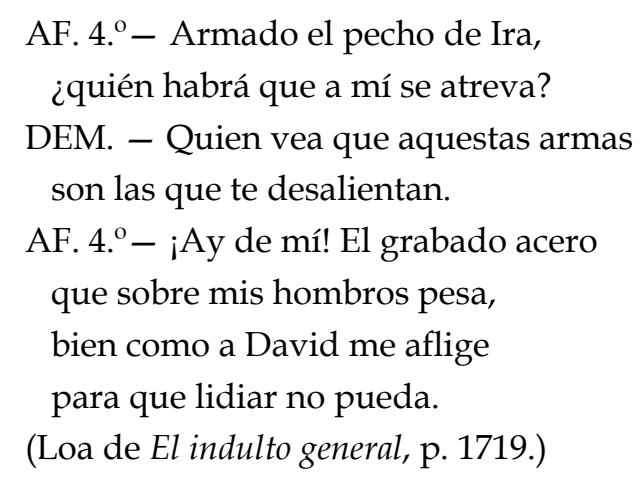

Pasando ya al plano alegórico de la loa sacramental, el recuerdo de la historia de la Redención - equivalente a la sintética oración del Credo en la iglesia - sirve también de catequesis para facilitar la comprensión del misterio de la Eucaristía por parte del espectador, a la vez que cumple la función de dar sentido alegórico al $\operatorname{argumento}^{35}$. El mejor ejemplo, por contener la mayor pluralidad de significados de la historia de la Salvación, es la loa de La Hermandad del Refugio. En ella, la Fe y la Esperanza leen a la Caridad, para que ésta les dé un remedio, los memoriales que han entregado varios menesterosos madrileños. La situación responde fielmente a la historia del siglo XVII y, sin embargo, el dar a esos necesitados nombres de historia sagrada hermosea el plano historial y, al mismo tiempo, lo enlaza con el plano alegórico, en el que se puede descifrar entonces una sucinta historia de la Salvación ${ }^{36}$. En concreto, la Caridad recibe memoriales - por este orden - de Adán y Eva, María

\footnotetext{
${ }^{35}$ En los géneros sacramentales, lo alegórico es tan dramático como lo historial; y así, la historia sagrada utilizada en ese plano no deja de ser también materia dramática y, en consecuencia, necesaria. Por esa razón, no puede obviarse aquí su estudio. Por el contrario, en otro tipo de obras -por ejemplo, en los dramas mitológicos- la alegoría de lo histórico es sólo una segunda lectura posible, pero prescindible, del argumento.

${ }^{36}$ Los nombres de las calles en las que viven los pobres (Amargura, Lavapiés, Cuesta de San Lázaro...), o de los lugares de Madrid a los que les manda la Caridad (las Arrepentidas, la Pasión...), también señalan al lector o espectador la necesidad de una interpretación alegórica de todo el texto. Para el doble significado del espacio en esta loa, vid. I. Arellano, "El espacio historial y místico en los autos de Calderón: la topografía transfigurada", en La dramaturgia de Calderón..., pp. 51-52.
} 
Magdalena, el paralítico de la piscina y Lázaro, Job, la samaritana, Dimas, San Pablo (citado arriba) y María y Jesús. Aunque no hay un orden cronológico estricto, la enumeración comienza y termina del mismo modo que la historia de la Salvación, y la muerte redentora de Jesús resulta perfectamente inteligible al espectador al recordársele la necesidad de reparación del pecado original:

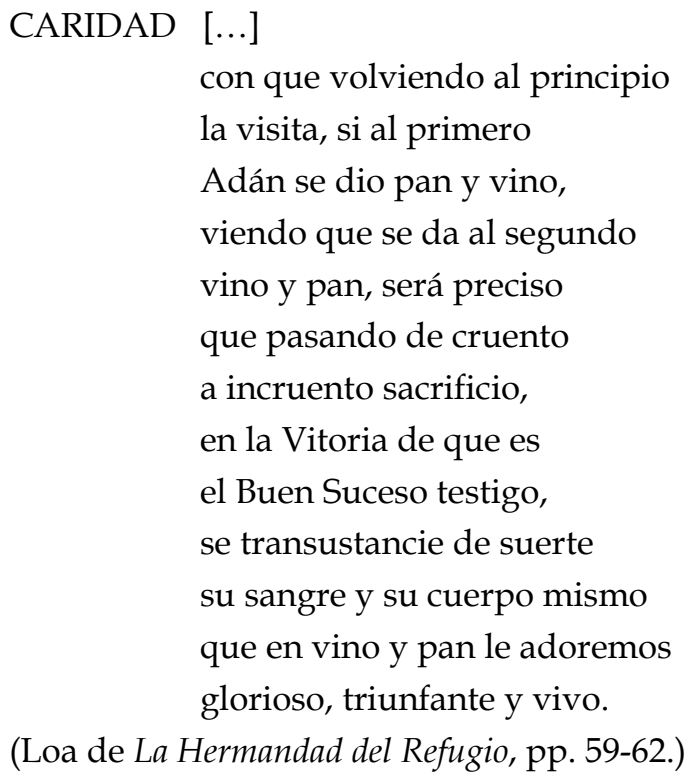

La mención algo arbitraria de otros nombres de historia sagrada entre los de Adán y Jesús responde a la idea de la muerte de Cristo como misterio de redención universal. Por eso, se alude a algunos personajes que fallecieron antes de la resurrección, como el paralítico de la piscina y Lázaro, que tuvieron, así, que esperar en el limbo (pp. 45-46), o, por el contrario, a Dimas, que murió con Él, o bien a San Pablo, ya posterior. En todos los casos, la mención de esos personajes condensa unos pocos rasgos distintivos, en los que se mezcla - siempre en el plano alegórico - la fuente bíblica con la tradición de la Iglesia, con el propósito de que el espectador recuerde fácilmente un relato histórico que conoce de sobra y no es necesario repetir; así la conversión de Pablo o la historia de María Magdalena:

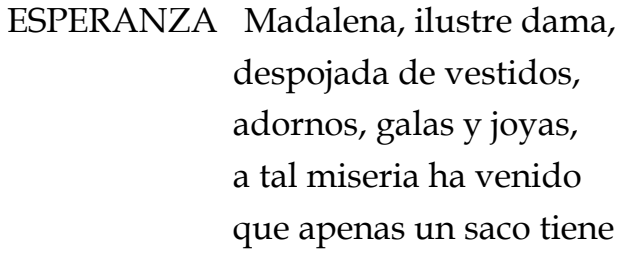




$\begin{array}{ll} & \begin{array}{l}\text { con que reparar el frío } \\ \text { y de amor enferma yace } \\ \text { alimentada a suspiros. }\end{array} \\ \begin{array}{ll}\text { CARIDAD } & \text { ¿Dónde vive? } \\ \text { ESPERANZA } & \multicolumn{1}{c}{\text { Al Lavapiés. }} \\ \text { CARIDAD } & \text { ¿Qué calle?, que es grande el sitio. } \\ \text { ESPERANZA } & \text { En la calle del Calvario } \\ \text { que es en aquel barrio mismo. }\end{array} \\ \begin{array}{ll}\text { CARIDAD } & \text { [...] dirás } \\ \text { que la lleven mis ministros... } \\ \text { ESPERANZA } & \text { ¿Dónde? } \\ \text { CARIDAD } & \text { A la Pasión, que es }\end{array} \\ \begin{array}{ll}\text { (Loa de La Hermandad del Refugio, pp. } 41 \text { y 43.) }\end{array}\end{array}$

Como se puede observar en este ejemplo, los personajes bíblicos mencionados pierden toda su historicidad en el plano historial y se convierten en un nombre más dentro de la vida cotidiana madrileña. En el plano alegórico, se desarrolla, en cambio, el sentido histórico y sagrado de ese nombre; aunque la historia bíblica recibe aquí más modificaciones que en su empleo como "menciones y adaptaciones de microtextos bíblicos", ya que este nuevo uso exclusivamente alegórico no se basa ya en la autoridad del texto, sino en su poder evocador y representativo de la historia de la Redención.

Una vez esquematizada, esa historia cumple - tanto en esta pieza como en el plano alegórico del resto de loas sacramentales - una función catequística, cuya obtención es muy similar a la del didactismo religioso derivado de la utilización argumentativa de referencias bíblicas, pues en ambos casos la intención del dramaturgo al recurrir a la historia sagrada es explicar el misterio de la Eucaristía al espectador con el propósito último de aumentar su fe. De este modo, en la loa de $L a$ Hermandad del Refugio, Calderón dilucida ese sacramento situando su origen en los dos acontecimientos principales de la historia de la Redención: la muerte y la resurrección de Cristo. En primer lugar, la Sagrada Forma es la sepultura del cuerpo de Jesucristo: 


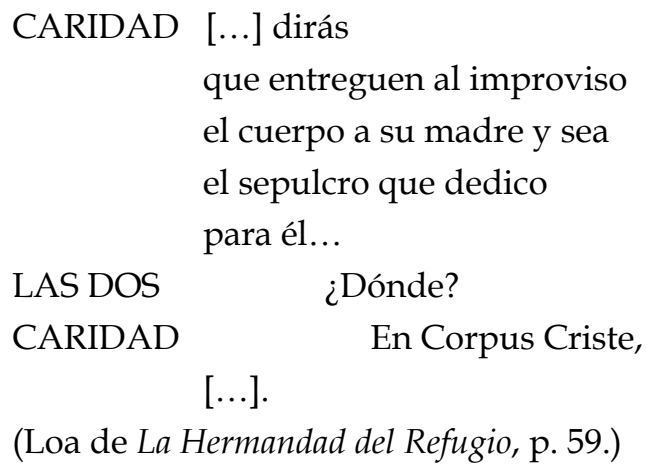

Esta etiología, que permite a los espectadores la inteligencia de la transubstanciación, nace de la unión de los hechos históricos de la institución de la Eucaristía por parte de Jesús (Marcos 14, 22) y de su entierro (Mateo 27, 57-61), pero añade la apariencia contemporánea debida al plano historial, donde sí tiene cabida la fábula. En segundo lugar, la evocación de la historia de la Redención aclara el carácter salvífico de la Eucaristía, pues ya se ha visto arriba cómo esta loa recuerda que la muerte de Cristo permitió la remisión del pecado original introducido por Adán en el mundo. En definitiva, cualquier intento de explicación de la Eucaristía por parte del dramaturgo recurre de forma inevitable a la historia de la Redención porque la Eucaristía es precisamente la imagen eterna de ese hecho histórico; no en vano la Iglesia la considera memorial de la pasión y resurrección de Cristo.

No se puede hablar, en cambio, de funciones celebradora y laudatoria de la historia sagrada en las loas sacramentales. La celebración y exaltación del misterio de la Eucaristía y, en última instancia, de Dios no es equivalente a la alabanza de la familia real en las loas cortesanas ni tampoco en las sacramentales. Ya se ha visto que Dios no es un personaje histórico como divinidad ni como presencia de Cristo en la Eucaristía. Su alabanza en todas las loas sacramentales es, por el contrario, la exaltación de lo eterno y verdadero frente a lo temporal y circunstancial. El papel que la historia sagrada cumple al respecto es el de catequizar al espectador hasta que se una a la exaltación de lo eterno. 
$\mathrm{Si}$, como se ha puesto de manifiesto, no hay diferencia entre las funciones que cumplen el Antiguo Testamento y el Nuevo en las loas sacramentales calderonianas, sino que la variedad de usos depende de factores internos de la pieza dramática, también las menciones de santos, en un contexto similar, cumplen la misma función que las de personajes bíblicos. En ambos casos interesa la sacralidad, acorde con el género dramático y apta para la alegoría y la catequesis. Por tanto, a diferencia de lo que ocurre en el teatro breve cómico, no se incluyen santos de historicidad dudosa, de cuya sacralidad se podría desconfiar; aunque, una vez asegurada su existencia real, no importan otros aspectos como la época histórica en que vivieron.

Naturalmente, en pasajes argumentativos, los santos citados deben ser al mismo tiempo Padres de la Iglesia, porque sólo sus textos tienen la misma autoridad que la Biblia en la tradición católica ${ }^{37}$. La misma función argumentativa, argumental y catequística desempeña la siguiente referencia a San Cipriano, Padre de la Iglesia, que la cita de unas palabras proféticas del rey David:

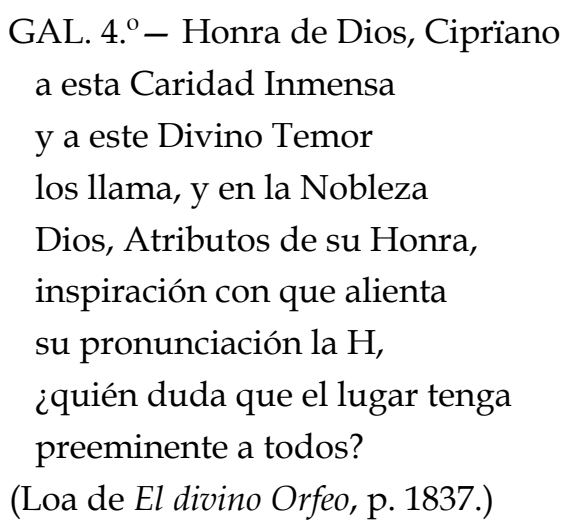

E igual que en el caso de los personajes bíblicos, en el plano alegórico, la mención de algunos santos le sirve a Calderón para unir ese plano con el historial y para ejemplificar con fines catequísticos la universalidad de la Redención. De nuevo, La Hermandad del Refugio contiene los ejemplos más diáfanos. Así, en esta loa, la

\footnotetext{
37 "Esta importancia de los Padres [...] tiene que ver también con el deseo de garantía ortodoxa frente a corrientes protestantes defensoras de la libre interpretación" (I. Arellano, Estructuras dramáticas y alegóricas..., p. 62).
} 
Caridad reside - como no podía ser de otro modo ${ }^{38}$ - en el Postigo de San Martín, "que es quien parte / la capa con el mendigo" 39 ; mientras que los santos Justo y Pastor, Agustín y Úrsula se encuentran entre los menesterosos con los que el dramaturgo evoca la historia de la Redención ${ }^{40}$.

${ }^{38}$ Es muy frecuente en el Siglo de Oro la identificación iconográfica entre San Martín y la Caridad. Vid. A. Egido, "Visajes de la pobreza en el Siglo de Oro", en De la mano de Artemia. Literatura, Emblemática, Mnemotecnia y Arte en el Siglo de Oro, Palma (Mallorca), José J. de Olañeta / Universitat de les Illes Balears, 2004, p. 162.

${ }^{39}$ Loa de La Hermandad del Refugio, p. 32.

40 Vid. ibid., pp. 52-56. 


\section{BIBLIOGRAFÍA}

ARELLANO, I., "Para el repertorio de loas sacramentales calderonianas. Un autógrafo inédito de Calderón: la loa auténtica de El Año Santo de Roma", Criticón, 62 (1994), pp. 7-32.

_ Estructuras dramáticas y alegóricas en los autos de Calderón, Pamplona / Kassel, Universidad de Navarra / Reichenberger, 2001.

“El espacio historial y místico en los autos de Calderón: la topografía transfigurada", en I. Arellano y E. Cancelliere (eds.), La dramaturgia de Calderón: técnicas y estructuras (Homenaje a Jesús Sepúlveda), Madrid / Frankfurt am Main, Iberoamericana / Vervuert, 2006, pp. 41-63.

__ y DUARTE, J. E., El auto sacramental, Madrid, Laberinto, 2003.

CAlderón de la BARCA, P., Obras completas. Tomo III: Autos sacramentales, ed. Á. Valbuena Prat, Madrid, Aguilar, 1952.

_ Loa en metáfora de la piadosa Hermandad del Refugio, ed. I. Arellano et alii, Pamplona / Kassel, Universidad de Navarra / Reichenberger, 1998.

CARMONA Muela, J., Iconografía de los santos, Madrid, Istmo, 2003.

CotArelo Mori, E., Ensayo sobre la vida y obras de D. Pedro Calderón de la Barca, Madrid / Frankfurt am Main, Iberoamericana / Vervuert, 2001.

DíEz BorQue, J. M., Teoría, forma y función del teatro español de los Siglos de Oro, Palma de Mallorca, José J. de Olañeta, 1996.

__ Los espectáculos del teatro y de la fiesta en el Siglo de Oro, Madrid, Laberinto, 2002.

EGIDO, A., "Visajes de la pobreza en el Siglo de Oro", en De la mano de Artemia. Literatura, Emblemática, Mnemotecnia y Arte en el Siglo de Oro, Palma (Mallorca), José J. de Olañeta / Universitat de les Illes Balears, 2004, pp. 151192. 
ERdocia Castillejo, C., Hacia una poética de la representación sacramental del Siglo de Oro español: las loas sacramentales de Calderón de la Barca y la celebración del Corpus Christi, Princeton University, 1997 [tesis doctoral].

PARKER, A. A., Los autos sacramentales de Calderón de la Barca, Barcelona, Ariel, 1983.

Pedraza Jiménez, F. B., Calderón. Vida y teatro, Madrid, Alianza, 2000.

Rodríguez CuAdros, E., Calderón, Madrid, Síntesis, 2002.

RuIz RAMón, F., Historia del teatro español (Desde sus orígenes hasta 1900), Madrid, Cátedra, 1996 (9a ed.).

Rull, E., “Hacia la delimitación de una teoría político-teológica en el teatro de Calderón", en L. García Lorenzo (ed.), Calderón. Actas del «Congreso Internacional sobre Calderón y el Teatro Español del Siglo de Oro». (Madrid, 8-13 de junio de 1981), Madrid, C.S.I.C., 1983, t. II, pp. 759-767. (ed.), Autos sacramentales del Siglo de Oro, Barcelona, Plaza \& Janés, 1986.

, “Instrucción y concelebración populares en el auto sacramental”, en J. Álvarez Barrientos y A. Cea Gutiérrez (eds.), Actas de las Jornadas sobre teatro popular en España, Madrid, C.S.I.C., 1987, pp. 53-63.

, “Apuntes para un estudio sobre la función teológico-política de la «loa» en el Siglo de Oro", en I. Arellano et alii (eds.), Apuntes sobre la loa sacramental y cortesana. Loas completas de Bances Candamo. Estudios y ediciones críticas, Kassel, Reichenberger, 1994, pp. 25-35.

__ , "El auto sacramental de Calderón como género. Un ejemplo: Psiquis y Cupido", en A. Egido (ed.), Lecciones calderonianas, Zaragoza, Ibercaja, 2001, pp.125-150.

SIMSON, I., "La función de la alegoría en las comedias de temática americana en el Siglo de Oro", en C. Strosetzki (ed.), Teatro español del Siglo de Oro. Teoría y práctica, Frankfurt am Main / Madrid, Vervuert / Iberoamericana, 1998, pp. 305-321.

SPANG, K., “Aproximación a la loa sacramental y palaciega: notas estructurales”, en I. Arellano et alii (eds.), Apuntes sobre la loa sacramental y cortesana. Loas 
completas de Bances Candamo. Estudios y ediciones críticas, Kassel, Reichenberger, 1994, pp. 7-24.

, “El auto sacramental como género literario", en I. Arellano et alii (eds.), Divinas y humanas letras. Doctrina y poesía en los autos sacramentales de Calderón. Actas del Congreso Internacional, Pamplona, Universidad de Navarra, 26 febrero-1 marzo, 1997, Pamplona / Kassel, Universidad de Navarra / Reichenberger, 1997, pp. 469-505.

TIETZ, M., “El «espectador implícito» de los autos sacramentales de Pedro Calderón de la Barca", en I. Arellano y E. Cancelliere (eds.), La dramaturgia de Calderón: técnicas y estructuras (Homenaje a Jesús Sepúlveda), Madrid / Frankfurt am Main, Iberoamericana / Vervuert, 2006, pp. 561-586.

ZAFRA, R., “La «estructura de cuestión» en las loas sacramentales calderonianas”, en I. Arellano y E. Cancelliere (eds.), La dramaturgia de Calderón: técnicas y estructuras (Homenaje a Jesús Sepúlveda), Madrid / Frankfurt am Main, Iberoamericana / Vervuert, 2006, pp. 625-636. 